\title{
PEMBANGUNAN DAERAH DALAM PENGEMBANGAN WISATA DESA BANRAAS PULAU GILI IYANG MADURA MELALUI KELOMPOK SADAR WISATA
}

\author{
${ }^{1}$ Enza Resdiana, ${ }^{2}$ Nur Inna Alfiyah, ${ }^{3}$ Laylatul Hasanah \\ FISIP, Universitas Wiraraja \\ Email: enza.resdiana@gmail.com, nurinna@wiraraja.ac.id, laylatulhasanah@wiraraja.ac.id
}

\begin{abstract}
The Tourism Awareness Group is a self-help group that grows from, by and for the community. The aim of the tourism awareness group aims to increase regional tourism development and the success of regional tourism development by becoming a partner of the government in increasing public awareness in the tourism sector, increasing human resources, encouraging the realization of Sapta Pesona and improving the quality of tourism products. This study used a qualitative descriptive method, where the subject and object of this study were the Banraas Tourism Awareness Group (Pokdarwis), Andang Taruna Village. The results showed that Pokdarwis Andang Taruna was able to be the motor to drive the community in an effort to create a conducive environment and atmosphere that was able to encourage the growth and development of tourism and the realization of Sapta Pesona. Meanwhile, in the role of partners with the government regarding the development and construction of tourism facilities, such as the realization related to lodging, transportation, culinary delights and others, it still needs to be reviewed to realize the caring character of tourism.
\end{abstract}

Keywords: Tourism Awareness Group, Regional Development, Tourism development

\section{PENDAHULUAN}

Kabupaten Sumenep gencar melakukan pembangunan wisata sebagai bentuk respon terhadap perkembangan pembangunan wisata yang dilakukan di wilayah lain, Kabupaten dengan pulau terbanyak di Jawa Timur adalah Kabupaten sumenep, dengan jumlah pulau 126 pulau (48 pulau berpenghuni dan 78 pulau tidak berpenghuni) (Peraturan Bupati Sumenep nomor11 tahun 2006). Kabupaten Sumenep terdiri dari 25 Kecamatan dan 331 desa. Luas total Kabupaten Sumenep 212.410,2 Ha. Luas kabupaten Sumenep mempunyai terumbu karang dan mangrove terluas dijawa Timur dengan kondisi yang masih baik dibandingkan dengan kabupaten lain di Jawa Timur. Hal ini menunjukkan wilayah Kabupaten Sumenep memiliki potensi sumber daya alam yang besar yang belum termanfaatkan.

Salah satu pulau kecil yang mulai dikenal oleh masyarakat adalah Pulau Gili Iyang yang terletak di dekat Pulau Madura tepatnya di kabupaten Sumenep. Pulau gili Iyang terletak di sebelah timur pulau Madura, tepatnya di Selat Sapudi Kabupaten Sumenep. Pulau ini terkenal dengan area memancing dan kadar oksigen yang cukup tinggi dibandingkan dengan daerah lain. Berdasarkan penelitian terakhir yang dilakukan Balai Besar Teknis Kesehatan Lingkungan dan Pengendalian Penyakit (BBTKL-PP), menurut Ketua Tim sekaligus Kepala BBTKL PP, Zainal Ilyas Nampira, hasil kajian sementara, kondisi oksigen (O2) mencapai 20, 9 hingga 21, 5 persen atau berada diatas ambang normal 20 persen. Kondisi kadar karbondioksida (CO) di Pulau ini juga bagus,berkisar antara 302-313 ppm, masih di bawah batas normal yang diperbolehkan di udara sebesar $387 \mathrm{ppm}$. Sementara tingkat kebisingan udara 36,5 - 37,8 dBA, di bawah baku mutu kebisingan wilayah pemukiman yaitu $55 \mathrm{dbA}$. (BBTKLPP Surabaya, 2013) Kondisi udara yang bersih dan tingginya kadar oksigen ini serta wisata alam yang terdapat disana yang menyebabkan Pemerintah Kabupaten Sumenep berencana menjadikan Pulau Gili Iyang sebagai obyek wisata kesehatan.

Pulau dengan luas sekitar $9 \mathrm{~km}$ itu terdiri dari dua desa yaitu desa Banraas dan Bancamara. 2 Pulau kecil ini menjadi menarik karena diyakini oleh masyarakat sebagai kawasan dengan kadar oksigen $(\mathrm{O} 2)$ tinggi, bahkan tertinggi kedua setelah Laut Mati. Keyakinan ini didukung oleh fakta 
bahwa penduduk Gili Iyang banyak yang mencapai usia tinggi dengan kondisi yang sehat dan kuat, sehingga munculah kepercayaan Gili Iyang ini menjadikan awet muda dan tak ayal Gili Iyang ini mendapat pula julukan pulau awet muda. Media masa pun banyak yang mewartakan tentang kondisi Gili Iyang tersebut (Tempo,2012; Tribunnews, 2013; Kompas, 2013;Koran Suara Rakyat, 2014; Detik, 2013).

Adanya potensi tersebut dilakukan pembangunan dan pengembangan wisata oleh Pemerintah Daerah. Disamping itu juga Pulau Gili iyang telah dijadikan sebagai objek pembangunan yang masuk dalam rencana induk pembangunan segitiga emas yaitu pulau gili iyang, gili labak dan gili genting yang akan menjadi sasaran untuk pengembangan wisata. Dalam pengembangan wisata tentunya dibutuhkan berbagai fasilitas yang tersedia seperti angkutan umu untuk sampai ke pelabuhan dungkek, angkutan laut yang tersedia selama 24 jam, fasilitas kendaraam untuk mengantarkan ketempat wisata, home stay atau tempat penginanpan yang ramah lingkungan, restoran atau rumah makan yang menyediakan makanan khas gili yang dan berbagai macam kebutuhan yang disediakan oleh Pemerintah maupun masyarakat setempat.

Tabel 1

Wisata yang tersedia di Giliiyang

\begin{tabular}{|c|l|}
\hline No. & \multicolumn{1}{|c|}{ Nama Wisata } \\
\hline 1. & Wisata Goa Air \\
\hline 2. & Wisata Goa Sarepa \\
\hline 3. & Wisata Goa Maharani \\
\hline 4. & Wisata batu Cangge \\
\hline 5. & Fosil Ikan \\
\hline 6. & Pantai Ropet \\
\hline 7. & Penginapan titik O2 \\
\hline
\end{tabular}

Adanya wisata di Gili Iyang yaitu seperti wisata Goa air, Goa Sarepa, Goa Maharani, wisata Batu Cangge Fosil ikan yang terletak di Banraas merupakan daya tarik dari pulau Gili iyang khususnya untuk dua desa yang berada di Pulau Gili iyang, sehingga perlu dilakukan pengembangan dan pembangunan dari pemerintah baik itu dari segi pembangunan fisik maupun dari segi pembangunan manusia yang ada disana. Munculnya berbagai potensi di Gili iyang membuat masyarakat lokal membentuk organisasi yang disebut dengan Pokdarwis yang bernamakan "Andang Taruna", pembentukan Pokdarwis ini merupakan respon masyarakat lokal yang mempunyai keperdulian akan pengembangan dan pembangunan wisata di desanya dengan beranggotakan masyarakat asli desa Giliiyang khususnya desa Banraas.

Terbentuknya Pokdarwis di titik pusat oksigen yaitu yang terletak di Desa Banraas memudahkan pemerintah untuk melakukan pembangunan dan pengembangan wisata, dalam hal ini Pokdarwis sebagai katalisator atau penghubung antara Pemerintah dan masyarakat untuk mengembangkan wisata sesuai dengan kearifan lokal di desa tersebut. Peran Pokdarwis andang taruna dapat memberikan pengaruh positif untuk kemajuan wisata pulau oksigen sehingga Pokdarwis sebagai penghubung antara kebijakan pemerintah dengan masyarakat dapat berjalan sesuai dengan yang diharapkan. Peran untuk memberikan pengetahuan dan pengertian kepada masyarakat untuk lebih peduli terhadap lingkungan wisata merupakan peran penting yang harus dilakukan untuk mewujudkan pengembangan wisata.

Berdasarkan data kunjungan wisatawan di pulau Gili iyang dapat dikatakan mengalami kenaikan jumlah pengunjung. Hal ini dapat dilihat dari tahun 2018 bulan pertama Januari Februari ada 197 wisatawan yang berkunjung sedangkan untuk tahun 2019 terdapat kunjungan wisatawan mancanegara 63 dan wisatawan nusantara 3.513. sedangkan untuk tahun 2020 wisata mulai dinonaktifkan terkait dengan penyebaran Covid-19 sehingga mengalami penurunan yang drastis. Hal itu dapat dilihat dari tabel berikut ini

\section{Tabel 2}

\section{Kunjungan wisatawan di Gili iyang Tahun 2018}

\begin{tabular}{|c|c|c|}
\hline No. & Bulan & Wisatawan \\
\hline 1. & Januari & 62 \\
\hline 2. & Februari & 135 \\
\hline \multicolumn{3}{|c|}{ Total (Lk+Pr) } \\
197Wisatawan \\
\hline
\end{tabular}

Tabel 3

Kunjungan wisatawan di Gili iyang tahun 2019

\begin{tabular}{|c|c|c|c|}
\hline No, & Bulan & Wisman & Wisnus \\
\hline 1. & $\begin{array}{l}\text { Januari- } \\
\text { Oktober }\end{array}$ & 63 & 3.513 \\
\hline \multicolumn{4}{|c|}{ Total (Lk+Pr) } \\
\hline \multicolumn{3}{|c|}{ 3.576 Wisatawan } \\
\hline
\end{tabular}

Berdasarkan penelitian awal yang dilakukan oleh peneliti yaitu dengan ketua pokdarwis Ahyak Ulumuddin yang menyebutkan 
bahwa Pokdarwis Andang Taruna Desa Banraas memiliki beberapa kelompok kerja yaitu Pokja Transportasi, Pokja Kuliner dan Sovenir, Pokja Destinasi. Sebagai penggerak sektor pariwisata Pokdarwis Andang Taruna menyediakan biro perjalanan/ travel lokal yaitu "Andang Taruna Tour and Travel" yang beralamat di Dusun Baru, RT. 05 / RW. 04, Desa Bandra'as, Dungkek, Banraas, Dungkek, Kabupaten Sumenep, Jawa Timur 69474, Indonesia. Wisatawan dapat memesan kebutuhan wisata mulai dari perjalanan dari pusat kota Sumenep, menuju Dermaga Kecamatan Dungkek hingga penyebrangan menuju pulau Gili Iyang sampai dengan sampai pada titik wisata yang di tuju. Disediakan juga bagi wisatawan yang ingin bermalam di pulau Gili Iyang dapat menyewa fasilitas Homestay yang tersedia yakni homestay "Pantai Ropet" yang dikelola pokdakwis dan homestay "Tanean Lanjang"yang dikelola oleh masyarakat lokal yaitu Ibu Farida. Homestay pantai ropet di fasilitasi oleh BPWS (Badan pengembangan wilayah Surabaya Madura).

Tersedianya berbagai fasilitas yang mendukung wisata Giliiyang tidak lepas dari peran Pokdarwis dalam memberikan pengaruh terhadap masyarakat lokal untuk menerima dan bersikap terbuka terhadap perkembangan zaman terutama untuk sektor wisata, selain sikap terbuka terhadap wisatawan dibutuhkan juga peran yang lain untuk membentuk karakter peduli wisata dengan mealalui berbagai kegiatan yang dilakukan oleh Pokdarwis Andang Taruna. Karakter peduli wisata dibutuhkan untuk membantu percepatan perkembangan yang dilakukan oleh pemerintah. Selama ini yang menjadi kendala dalam setiap pengembangan wisata terletak pada subyek utama yaitu masyarakat oleh sebab itu dibutuhkan peran serta masyarakat itu sendiri untuk secara mandiri mampu mengembangkan wisata dengan inisiatif dan partisipasi dari masyarakat oleh sebab itu, dibutuhkannya karakter yang tertanam dalam masyarakat sebagai masyarakat yang peduli akan wisata yang berada dalam lingkungannya.

Berdasarkan dari penjelasan diatas maka peneliti tertarik untuk melakukan studi terkait degan Peran Pokdarwis Andang Taruna dalam menjalankan tugas dan fungsinya sebagai organisasi internal masyarakat. Dimana dalam tupoksinya Pokdarwis diharapkan agar mampu untuk mewujudkan masyarakat yang peduli dengan wisata, serta dapat mensukseskan pembangunan daerah dalam pengembangan wisata. Dari latar belakang diatas maka peneliti memilih judul
"Pembangunan Daerah Dalam Pengembangan Wisata Desa Banraas Pulau Gili Iyang Madura Melalui Kelompok Sadar Wisata".

\section{TINJAUAN PUSTAKA}

Pembangunan daerah merupakan agenda pembangunan nasional yang bertujuan untuk mengelola sumber-sumber daya yang ada yang bertujuan untuk menciptakan lapangan pekerjaan dan dapat merangsang kegiatan ekonomi dalam daerah sahingga tujuan pembangunan dan kesejahteraan masyarakat dapat terwujud. Pembangunan daerah semakin di galakkan mulai tahun 2001 saat otonomi daerah mulai diberlakukan di berbagai daerah. Hal ini kemudian memicu pemerintah daerah untuk melakukan pembangunan daerah di berbagai sektor dan pemanfaatan sumber daya alam yang ada untuk menunjang kesejahteraan ekonomi daerah yang bersangkutan. Salah satu pembangunan daerah yang paling banyak dimanfaatkan oleh berbagai pemerintah daerah di Indonesia adalah pembangunan daerah di sektor pariwisata.

Pariwisata merupakan suatu aktivitas yang kompleks yang dapat dipandang sebagai suatu sistem yang besar, yang terdiri dari beragam komponen seperti ekonomi, ekologi, politik, sosial, budaya dan seterusnya. Ketika pariwisata dipandang sebagai sebuah sistem, maka analisis tentang kepariwisataan tidak bisa dilepaskan dari subsistem yang lain, seperti politik, sosial ekonomi, budaya dan seterusnya. Pemahaman mengenai pariwisata sebagai suatu sistem tersebut menunjukkan bahwa terdapat banyak aktor yang terlibat serta memiliki peran dalam menggerakkan sistem pariwisata. Aktor-aktor tersebut, baik individu maupun kelompok, disebut pula sebagai insan-insan pariwisata yang ada pada berbagai sektor yang terkait dengan pariwisata. Secara umum, insan-insan pariwisata dikelompokkan dalam tiga pilar utama, yaitu: (1) masyarakat, (2) swasta, dan (3) pemerintah. Pilar masyarakat merujuk pada masyarakat umum yang ada pada destinasi atau lokasi wisata, sebagai pemilik sah dari berbagai sumber daya yang merupakan modal pariwisata seperti kebudayaan. Termasuk didalamnya tokoh-tokoh masyarakat, intelektual, Lembga Swadaya Masyarakat, dan media massa. Salah satu peran yang sangat vital dari perkembangan pariwisata di daerah adalah dengan munculnya kelompok -kelompok sadar wisata.

Disamping itu berdasar hasil penelitian yang berjudul Pengembangan Pariwisata Berbasis 
Masyarakat menghasilkan bahwa pengambangan pariwisata dengan menggunakan pendekatan masyarakat (the community approach) dapat berhasil karena melibatkan masyarakat sebagai pelau penting dalam pengembangan pariwisata. Hal ini dikarenakan masyarakat mampu memahami kondisi alam sekitar pariwisata tersebut ada. Sehingga tahap-tahap pengembangan strategi seperti strategi direktif (instruktif), hingga tahap lanjutan seperti strategi partisipatif dapat dijalankan dengan baik (Suta \& Mahagangga, 2018).

\section{Kelompok Sadar Wisata}

Kelompok sadar wisata merupakan salah satu komponen dalam masyarakat yang memiliki peran dan kontribusi penting untuk membentuk kesadaran masyarakat akan pembangunan pariwisata di daerahnya. Undang-undang No 10 Tahun 2009 tentang Kepariwisataan menjelaskan bahwa Kelompok Sadar Wisata dapat dipahami sebagai kelompok yang tumbuh atas inisiatif dan kesadaran masyarakat untuk berpartisipasi aktif memelihara dan melestarikan berbagi obyek wisata dan daya tarik wisata dalam rangka meningkatkan pembangunan pariwisata di daerah tempat tinggalnya. Sebagai stakeholder maupun motor penggerak dalam pengembangan potensi wisata di daerahnya pada hakikatnya Pokdarwis dapat melaksanakan berbagai jenis kegiatan yang disesuaikan dengan keadaan dan kondisi masingmasing kelompok ( Farida dkk, 2017).

Sedangkan menurut Ingga Purwanti dalam Strategi Kelompok Sadar Wisata dalam Penguatan Desa Wisata, memberikan hasil bahwa kelompok sadar wisata harus memiliki strategi. Salah satu strategi yang dijalankan oleh kelompok sadar wisata adalah strategi inovatif dengan membuat program-program dan mengatur langkah-langkah atau tindakan (action), agar organisasi non profit selalu tampil sebagai pelopor pembaharuan dalam bidang pemerintah khususnya dalam tugas pokok masing-masing. Disamping itu juga dengan mempertimbangkan pentingnya masyarakat mengetahui strategi pokdarwis tersebut untuk meningkatkan pemahaman dan pengetahuan pokdarwis terhadap posisi, peran dan kedudukannya dalam konteks pembangunan kepariwisataan di daerahnya. Meningkatkan kapasitas dan peran aktif pokdarwis dalam pembangunan kepariwisataan di daerahnya khususnya dalammewujudkansadarwisata dan sapta pesona (Wisatawan, 2017).
Maksud Pembentukan Kelompok Sadar Wisata Menurut buku Panduan Kelompok Sadar Wisata (2012: 17) maksud dari pembentukan kelompok sadar wisata adalah mengembangkan kelompok masyarakat yang dapat berperan sebagai motivator, penggerak serta komunikator dalam upaya meningkatkan kesiapan dan kepedulian masyarakat di sekitar destinasi pariwisata agar dapat berperan sebagai tuan rumah yang baik, serta memiliki kesadaran akan peluang dan nilai manfaat yang dapat dikembangkan dari kegiatan pariwisata untuk meningkatkan kesejahteraan ekonomi masyarakat.

Tujuan Kelompok Sadar Wisata Menurut buku panduan Kelompok Sadar Wisata (2012: 18) Tujuan dari pembentukan kelompok sadar wisata (Pokdarwis) adalah:

a) Meningkatkan posisi dan peran masyarakat sebagai subjek atau pelaku penting dalam pembangunan kepariwisataan. Serta dapat bersinergi dan bermitra dengan stakeholders yang terkait dalam peningkatan kualitas pengembangan kepariwisataan di daerah.

b) Membangun dan menumbuhkan sikap dan dukungan positif masyarakat sebagai tuan rumah melalui perwujudan nilai-nilai Sapta Pesona bagi tumbuh dan berkembangnya kepariwisataan di daerah dan manfaatnya bagi pembangunan daerah maupun kesejahteraan masyarakat.

c) Memperkenalkan, melestarikan dan memanfaatkan potensi daya tarik wisata yang ada di masing-masing daerah.

\section{Fungsi Kelompok Sadar Wisata}

Menurut buku panduan Kelompok Sadar Wisata (2012: 18) dijelaskan secara umum, fungsi Pokdarwis dalam kegiatan kepariwisataan adalah:

a) Sebagai penggerak Sadar Wisata dan Sapta Pesona di lingkungan objek pariwisata.

b) Sebagai Mitra Pemerintah dan pemerintah daerah (kabupaten/kota) dalam upaya perwujudan dan pengembangan sadar wisata di daerah tersebut. Fungsi dari Kelompok Sadar Wisata yaitu sebagai penggerak sadar wisata dan Sapta Pesona, sebagai mitra pemerintah dalam mewujudkan dan pengembangan wisata di daerah tersebut. 


\section{METODE PENELITIAN}

Pada penelitian ini peneliti dalam mengkaji masalah menggunakan metode penelitian kualitatif untuk menentukan cara mencari, mengumpulkan, mengolah dan menganalisis data hasil penelitian. Metode penelitian kualitatif digunakan untuk memahami interaksi sosial, dimana objek penelitian yang dijadikan penelitian atau yang menjadi titik perhatian penelitian ini adalah Kelompok Sadar Wisata (Pokdarwis) Andang Taruna desa Banraas. Teknik analisa data, yang dilakukan yaitu; pertama, reduksi data yang merupakan proses pemilihan, pemusatan, perhatian pada penyederhanaan data dari semua data yang diperoleh baik melalui observasi, wawancara dan studi pustaka terhadap pihak-pihak terkait. Kedua, penyajian data dilakukan dengan proses pengorganisasian untuk memudahkan data dianalisis dan disimpulkan. Ketiga, penarikan kesimpulan, yaitu membuat pernyataan atau kesimpulan secara bulat tentang suatu permasalahan yang diteliti dalam bahasa yang deskriptif dan bersifat interpretative (Moleong, 2007:248).

\section{HASIL DAN PEMBAHASAN}

Pulau Gili Iyang adalah salah satu daerah di Kabupaten Sumenep, yang saat ini sedang mengalami perkembangan, salah satunya adalah pengembangan dalam sektor wisata alam dan bahari. Jumlah penduduk Pulau Gili Iyang tahun 2016 berdasarkan data yang diperoleh dari UPT Duk Capil Kecamatan Dungkek Kabupaten Sumenep penduduk pulau ini mencapai 8453 jiwa. Laki-laki 3907 jiwa dan perempuan 4546 jiwa.

\section{Tabel 4}

Data Penduduk Gili Iyang 2016

\begin{tabular}{|l|l|l|}
\hline No & Laki-Laki & Perempuan \\
\hline 1 & 3.907 jiwa & 4.546 jiwa \\
\hline \multicolumn{2}{|c|}{ Total (Lk+Pr) } & 8.453 Jiwa \\
\hline
\end{tabular}

Sumber : UPT Duk Capil Kecamatan Dungkek Kabupaten Sumenep

Mata pencarian masyarakat Pulau Gili Iyang Desa Banraas sebagian besar adalah bergerak di sektor perikanan, di samping ada juga yang menjadi PNS, guru, pedagang, petani, pengrajin gelang dan lain-lain. Keadaan bahasa yang dipakai masyarakat setempat pada umumnya menggunakan bahasa madura, dengan kondisi masyarakat yang masih tradisional dan terpaku dalam adat dan tradisi masyarakat lokal.
Untuk sampai ke pulau gili iyang membutuhkan beberapa jalur yaitu jalur darat dan jalur laut untuk jalur darat dari kota sumenep harus menempuh ke pelabuhan dungkek terlebih dahulu untuk sampai ke tujuan. Dari pelabuhan dungkek menuju pulau gili iyang ada perahu motor nelayan yang siap untuk mengantar penumpang ketujuan dengan tarif Rp. 10.000/orang. Setiap harinya perahu nelayan beroperasi sekitar jam 10 pagi sedangkan untuk penumpang yang datang dengan rombongan bisa sewa perahu pulang-pergi dengan biaya sekitar Rp. 400.000 yang dapat memuat kurang lebih 30 orang penumpang, sedangkan untuk menyewa perahu yang lebih kecil biaya sewa sekitar Rp. 200.000 dengan kapasitas muatan 1015 orang.Waktu yang diperlukan untuk sampai ke Gili iyang dari pelabuhan dungkek ke pulau Gili iyang sekitar 45-60 menit jika cuaca normal. Setelah tiba dipulau gili iyang disediakan carter kendaraan bermotor roda tiga untuk sampai ke tempat tujuan titik kaya oksigen. Berikut gambar beberapa wisata Gili iyang dan fasilitasnya
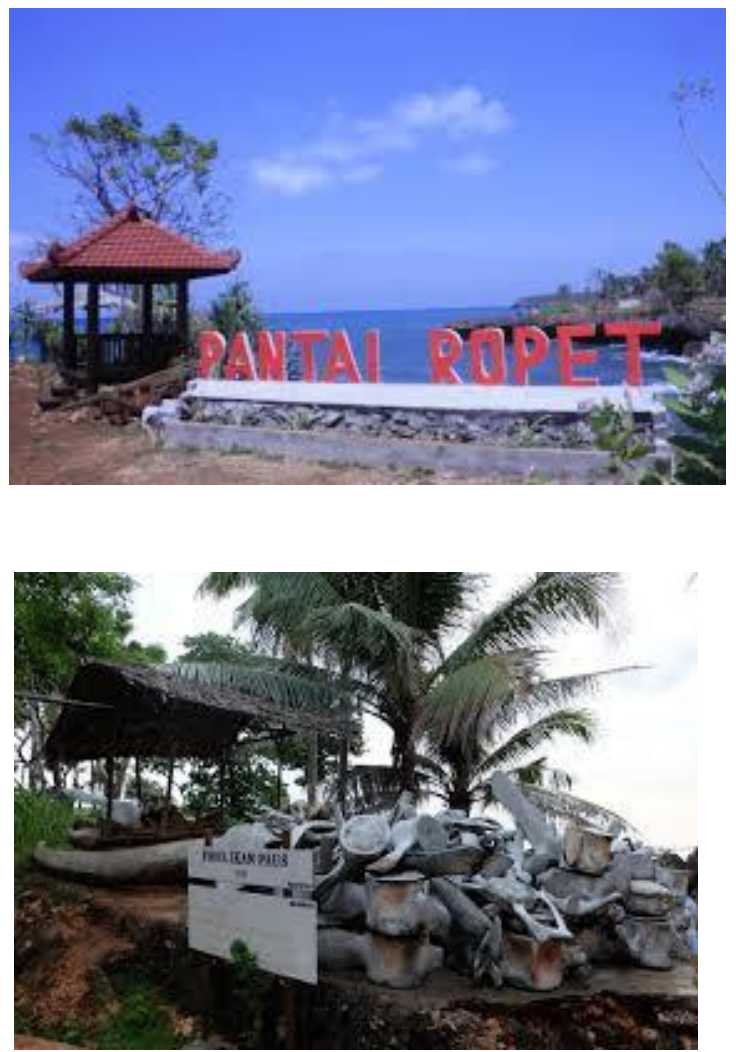

Pantai Ropet Banraas Fosil ikan Hiu 


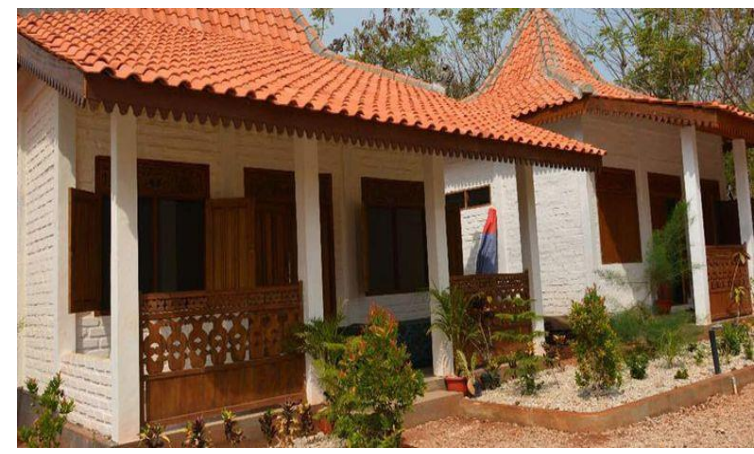

Homestay di Desa Banraas

Pulau Gili Iyang terkenal karena dipercaya memiliki kadar oksigen yang tinggi.Oksigen merupakan gas yang vital dibutuhkan dalam kehidupan manusia, sehingga kepercayaan akan kadar oksigen yang tinggi dijadikan sebagai dasar untuk pembangunan dan pengembangan di Gili Iyang yaitu sebagai tujuan wisata kesehatan. Pengecekan kadar oksigen di Gili Iyang dilakukan oleh beberapa instansi. Hasil pengukuran di lapangan oleh LAPAN (2006) dan analisisnya menunjukkan bahwa kadar oksigen di Gili Iyang dalam kondisi normal yaitu sebesar 20,9\%. Segarnya udara di Gili Iyang bukan karena kadar oksigen yang tinggi, tetapi karena udaranya bersih dari zat pencemar. Jika ada pengukuran dari instansi lain yang menunjukkan adanya titik spot dengan kadar oksigen yang tinggi di atas $22 \%$, sebetulnya kadar oksigen yang tinggipun perlu diwaspadai karena kadar oksigen yang tinggi bisa menyebabkan keracunan oksigen yang disebut hiperoksia dan berpotensi menyebabkan kebakaran yang dahsyat. Oleh karena itu menjadikan Gili Iyang sebagai tujuan wisata kesehatan dengan alasan memiliki kadar oksigen tinggi masih memerlukan kajian yang lebih mendalam.

Dalam daftar kunjungan wisatawan yang mengunjungi wisata Sumenep pada tahun 20182019 mengalami kenaikan pengunjung hal ini terkait dengan promosi yang dilakukan oleh Pemerintah Daerah. Begitupun juga untuk wisata Gili iyag yang mulai terekspos oleh publik sejak tahun 2014 akan tetapi mulai mulai datang kunjungan dari wisatawan sejak diadakannya program visit 2018 yang diagendakan oleh Pemerintah Daerah. Berikut daftar pengunjung wisata yang disajikan dalam bentuk tabel berikut ini.
Tabel 5

Data jumlah Kunjungan Wisata Nusantara

(Wisnus) dan Wisatawan mancanegara Tahun 2019 (mulai Januari hingga Desember

\begin{tabular}{|c|c|c|c|}
\hline No. & Nama Wisata & Wisman & Wisnus \\
\hline 1. & Asta Gumuk & 0 & 1.155 \\
\hline 2. & Asta Jokotole & 0 & 22.339 \\
\hline 3. & Asta K. Faqih & 0 & 7.326 \\
\hline 4. & Asta Katandur & 0 & 6.605 \\
\hline 5. & Asta Panaongan & 0 & 100.500 \\
\hline 6. & $\begin{array}{ll}\text { Asta } & \text { Sayid } \\
\text { Yusuf } & \end{array}$ & 0 & 179.253 \\
\hline 7. & Gili iyang & 63 & 3.513 \\
\hline 8. & Gili Labek & 109 & 36.913 \\
\hline 9. & $\begin{array}{l}\text { Makam asta } \\
\text { tinggi }\end{array}$ & 0 & 208.177 \\
\hline 10. & Masjid Jamik & 275 & 41.088 \\
\hline 11. & $\begin{array}{l}\text { Museum dan } \\
\text { Keraton }\end{array}$ & 305 & 31.934 \\
\hline 12. & Pantai 9 & 753 & 38.955 \\
\hline 13. & Pantai Badur & 0 & 17.145 \\
\hline 14. & Pantai Lombang & 18 & 31.329 \\
\hline 15. & Pantai Slopeng & 0 & 34.425 \\
\hline 16. & $\begin{array}{ll}\text { Rumah } & \text { Kasur } \\
\text { Pasir } & \\
\end{array}$ & 0 & 1.362 \\
\hline 17. & Situs Benteng & 0 & 935 \\
\hline 18. & Situs Batu Gong & 0 & 4.933 \\
\hline 19. & Bukit Tinggi & 0 & 26.574 \\
\hline 20. & Taman Tectona & 0 & 6.361 \\
\hline 21. & Mutiara Tirta & 0 & 63.908 \\
\hline 22. & $\begin{array}{ll}\text { Tirta } & \text { Sumekar } \\
\text { Indah } & \end{array}$ & 0 & 11.856 \\
\hline 23. & Batu Kapur & 0 & 10.150 \\
\hline 24. & $\begin{array}{ll}\text { Water } & \text { Park } \\
\text { Sumekar } & \\
\end{array}$ & 0 & 69.337 \\
\hline 25. & Goa Kuning & 0 & 1.168 \\
\hline 26. & Bukit Kalompek & 0 & 4.846 \\
\hline 27. & Sarkampoeng & 0 & 3.758 \\
\hline 28. & Telaga Kirmata & 0 & 6.658 \\
\hline 29. & Event Sumenep & 64 & 67.130 \\
\hline
\end{tabular}

Sumber : Disparbudpora Sumenep

\section{Pokdarwis Andang Taruna sebagai Penggerak}

Peran seseorang maupun lembaga dalam masyarakat sangat erat kaitannya dengan apa yang diharapkan dari seseorang maupun lembaga tersebut. Maka peran Kelompok Sadar Wisata adalah sesuatu yang diharapkan dari Kelompok Sadar Wisata itu sendiri untuk kebaikan, pengembangan, kontribusi dan pembangunan pariwisata di lingkungan sekitar objek wisata. Oleh karena itu peran dari

30 | Enza Resdiana, Nur Inna Alfiyah, Laylatul Hasanah | Pembangunan Daerah...... 
pengelola wisata, dari Pokdarwis (kelompok sadar wisata) dan juga dari masyarakat yang berada di suatu wilayah dekat dengan objek wisata tersebut sangat penting, juga peran tersebut dapat membantu mengembangkan objek wisata tersebut. Tanpa adanya peran dan kontribusi dari Pokdarwis, masyarakat dan pengelola maka objek wisata tersebut tidak dapat berkembang.

Berdasarkan Undang-undang No 10 Tahun 2009 tentang Kepariwisataan menjelaskan bahwa Kelompok Sadar Wisata dapat dipahami sebagai kelompok yang tumbuh atas inisiatif dan kesadaran masyarakat untuk berpartisipasi aktif memelihara dan melestarikan berbagi obyek wisata dan daya tarik wisata dalam rangka meningkatkan pembangunan pariwisata di daerah tempat tinggalnya. Sebagai stakeholder maupun motor penggerak dalam pengembangan potensi wisata di daerahnya pada hakikatnya Pokdarwis dapat melaksanakan berbagai jenis kegiatan yang disesuaikan dengan keadaan dan kondisi masing-masing kelompok ( Farida dkk, 2017).

Pembentukan pokdarwis Andang Taruna dibentuk berdasarkan kesadaran masyarakat akan maraknya wisata-wisata baru yang bermunculan pada tahun 2014, oleh sebab itu pokdarwis Andang Taruna menyadari bahwa di Desa Banraas juga mempunya potensi yang besar dalam hal wisata, sejak itu pokdarwis dibentuk dengan memilki tugas dan fungsi untuk mengembangkan wisata dan dapat memberikan dampak positif berupa kesejahteraan masyarakat desa semakin meningkat. Dalam teori yang dijelaskan bahwa Pokdarwis merupakan motor penggerak dalam pengembangan wisata dengan melakukan berbagai kegiatan untuk mengembangkan potensi yang ada, sama halnya yang dilakukan oleh Pokdarwis Andang Taruna melakukan kegiatan pemberdayaan masyarakat dengan dikemas "rembuk desa" untuk memberikan pemahaman mengenai pentingnya ikut serta dalam pengembangan yang dilakukan.

Pembentukan pokdarwis Andang Taruna berdasarkan atas buku panduan dan prosedural yang lain sehingga dengan begitu program yang dilakukan oleh Pokdarwis Andang Taruna yang pertama dilakukan yaitu dengan memberikan pemahaman kepada penduduk setempat untuk mampu menerima dan memperlakukan pengunjung denngan sebaik mungkin dengan menyediakan berbagai fasilitas yang dibutuhkan. Untuk mengubah masyarakat memang tidak mudah, banyak hal yang dilakukan oleh Pokdarwis agar masyarakat memililki kesadaran akan peduli wisata. Mengubah mindset masyarakat mengenai pembangunan wisata berarti tanah leluhur mereka akan dijual atau digadaikan kepihak yang lain membutuhkan berbagai upaya untuk mengubah hal tersebut akan tetapi perubahan yang dilakukan oleh Pokdarwis Andang taruna sangatlah besar, mengingat dalam wawancara yang menyatakan bahwa masyarakat telah bersikap terbuka kepada pengunjung yang datang dengan disediakannya penginapan di rumah penduduk. Menyediaan kuliner dan berbagai kebutuhan yang lain merupakan perubahan positif dalam menerapkan masyarakat peduli wisata.

Upaya yang dilakukan oleh pokdarwis dalam memberikan pemahaman kepada masyarakat merupakan bagian dari Substansi pemberdayaan yaitu memampukan dan memandirikan masyarakat. Pemberdayaan bukan hanya meliputi penguatan individu anggota masyarakat, tetapi juga pranatapranatanya. Menanamkan nilai-nilai budaya modern seperti kerja keras, hemat, keterbukaan, kebertanggungjawaban, disebut-sebut sebagai bagian dari upaya pemberdayaan itu. Dengan dilakukannya pemberdayaan tersebut perlahan masyarakat mampu untuk melakukan berbagai kegiatan terkait dengan wisata, misalnya dengan dibukanya rumah masyarkat, dibukanya kuliner khas masyarakat desa serta masyarakat telah mampu menerapkan konsep dari sapta pesona dilingkungan wisata Desa Banraas.

Upaya yang juga dilakukan oleh Pokdarwis Andang Taruna dapat dirasakan dengan jumlah kunjungan yang meningkat pada tahun 2019 yang dapat dilihat dalam tabel berikut

Tabel 6

Kunjungan wisatawan di Gili iyang Tahun 2018-2019

\begin{tabular}{|c|c|c|}
\hline \multicolumn{3}{|c|}{ Tahun 2018 } \\
\hline No. & Bulan & Wisatawan \\
\hline 1. & Januari & 62 \\
\hline 2. & Februari & 135 \\
\hline \multicolumn{2}{|c|}{ Total (Lk+Pr) Wisatawan } \\
\hline
\end{tabular}




\begin{tabular}{|c|c|c|c|}
\hline \multicolumn{4}{|c|}{ Tahun 2019 } \\
\hline No. & Bulan & Wisman & Wisnus \\
\hline 1. & $\begin{array}{c}\text { Januari- } \\
\text { Oktober }\end{array}$ & 63 & 3.513 \\
\multicolumn{4}{|c|}{ Total (Lk+Pr) } \\
\hline \multicolumn{3}{|c|}{ 3.576 Wisatawan } \\
\hline
\end{tabular}

Sumber : Disparbudpora Sumenep

Menurut Buku panduan Pokdarwis (2012) Sapta Pesona, adalah jabaran konsep Sadar Wisata yang terkait dengan dukungan dan peran masyarakat sebagai tuan rumah dalam upaya untuk menciptakan lingkungan dan suasana kondusif yang mampu mendorong tumbuh dan berkembangnya industri pariwisata, melalui perwujudan unsur aman, tertib, bersih, sejuk, indah, ramah dan kenangan.

Dalam hal ini perwujudan dari adanya sapta pesona telah dirasakan di lingkungan masyarakat desa hal ini dibicarakan dalam beberapa wawancara yang dilakukan bahwa masyarakat telah mampu menerima pengunjung dengan suasana yang aman, tertib, bersih, sejuk, indah, ramah, dan kenangan. Pokdarwis dan aparat desa secara sadar telah melakukan bersih-bersih dilingkungannya hal ini merupakan perubahan yang baik untuk tumbuhnya kesadara peduli wisata. Akan tetapi untuk pembelian kenang-kenangan desa masih belum ada, hal ini juga menjadi kendala dari wisata yang lain yang berada di kabupaten sumenep dimana pengunjung masih sulit untuk menemukan oleh-oleh atau souvenir.

Berdasarkan teori desa wisata, potensi yang dimiliki oleh Gili iyang memang sudah termasuk dalam teori desa wisata menurut Muliawan menyebutkan, bahwa Desa Wisata ialah desa yang memiliki potensi keunikan dan daya tarik wisata yang khas, baik berupa karakter fisik lingkungan pedesaan, maupun kehidupan sosial budaya kemasyarakatan yang dikelolah dan dikemas secara menarik dan alami. Meskipun potensi yang dimiliki besar akan tetapi jika para aktor wisata seperti Pokdarwis ataupun yang lain tidak dapat mengelola dan mengemas secara menarik maka wisata tersebut hanya akan bertahan sementara. Menyadari bahwa wisatawan sumenep hanya tertarik untuk melihat kondisi dan situasi yang berada di desa tertebut dan apalagi desa wisata Gili iyang tidak dapat memberikan kenangan yang indah maka sulit untuk pengunjungi lagi wisata tersebut, disinilah diperlukan peran serta pokdarwis untuk dapat menggerakkan masyarakat agar mampu secara bersama membangun karakter wisata yang unik. Berdasarkan observasi yang dilakukan belum ada daya tark yang kuat untuk pengunjung datang kembali ke wisata tersebut meskipun secara alam memang bagus

\section{Pokdarwis Andang Taruna sebagai Mitra}

Peran sebagai mitra dalam hal ini berkaitan dengan kerja sama antara pokdarwis dan Pemerintah. Peran pemerintah sebagai regulator dan fasilitator cukup memberikan ruang kepada masyarakat untuk berperan dalam berbagai pembangunan yang dilakukan sedangkan sebagai mitra kerja Pokdarwis mewakili masyarakat untuk berperan aktif dalam pelaksanaan pembangunan yang akan dilakukan. Dalam hal ini Pokdarwis berperan sebagai penyambung dalam keinginan masyarakat agar masyarakat tidak dirugikan atas berbagai macam pembangunan yang dilakukan apalagi terkait dengan membangunan wisata yang akan dilakukan di Desa. Dimana kepemilikan tanah wisata yang ditempati oleh wisata merupakan tanah asli masyarakat desa.

Peran pemerintah pada dasarnya hanya sebagai regulator dan fasilitator, sementara masyarakat lokal sendiri adalah aktor utama dalam mengelola dan mengembangkan potensi objek wisata. Dalam hal ini masyarakat menjadi aktor utama dalam mengelola dan mengembangkan potensi wisata yang ada (Sentanu \& Mahadiansar, 2020). Peran pokdarwis mampu merespon berbagai kebijakan yang dilakukan oleh Pemerintah dengan memperhatikan kondisi dan situasi masyarakat desa yang terdampak pembangunan objek wisata. Dalam hal ini Pokdarwis memiliki peran dalam berbagai indikator yaitu:

1. Peran dalam pengembangan objek wisata, peran dalam pengembangan wisata dapat berupa dibentuknya kerja sama atau mitra di wisata misalkan mitra terkait dengan penyediaan sampan untuk sampai ke lokasi wisata seperti yang dilakukan oleh aparat desa banraas dengan penyediaan trasnsportasi laut, penyediaan penginapan yang dibangun oleh Pemerintah seperti homestay yang terdapat di pantai ropet sementara untuk penginapan yang menjadi titik oksigen tertinggi dapat menginap di rumah masyarakat. 
2. Peran dalam kegiatan program-program kerja, program kerja yang dilakukan pokdarwis berdasarkan atas Pokja yang dibentuk yang dapat bekerja sama dengan Pemerintah yang berlaku sebagai fasilitator dalam menjalankan program kerja pokdarwis.

3. Peran dalam pengembangan Sumber Daya Manusia, dalam pengembangan sumber daya manusia pokdarwis dapat bermitra dengan pemerintah dimana pokdarwis Andang Taruna mendapatkan pelatihan kepariwisataan dengan hal ini dapat ditularkan kepada masyarakat sehingga masyarakat mampu untuk mengelola wisatanya.

Pokdarwis merupakan ujung tombak dari desa wisata dalam hal pelayanan dan penyediaan sarana bagi para wisatawan. Karena dari komunitas inilah kepuasan para wisatawan ditentukan. Mengingat penting dan strategisnya peran tersebut, maka diperlukan Peningkatan kapasitas bagi Pokdarwis Andang Taruna agar memiliki pengetahuan dan keterampilan yang baik. Melalui program pendidikan (internalisasi) dan penerapan sapta pesona wisata. Dengan begitu pokdarwis memiliki bekal pengetahuan dan keterampilan yang baik dalam mengelolah desa wisata Sapta pesona wisata yang merupakan dasar pengetahuan yang wajib dimiliki dan terinternalisasi dalam sikap dan perilaku para pelaku wisata dipilih sebagai tema pendidikan/pelatihan kali ini. Sapta Pesona yang berarti tujuh pesona wisata mengandung unsur kenyamanan, keamanan, kebersihan, keindahan, keasrian, keramahan, dan Kenangan merupakan prasyarat mutlak bagi pelaku wisata dalam mengelolah daerah/desa wisata.

Berdasarkan tingkat perkembangannya, desa wisata dibagi menjadi 3 yaitu Desa Wisata Embrio, desa yang mempunyai potensi wisata yang dapat dikembangkan menjadi desa wisata dan sudah mulai ada gerakan masyarakat/desa untuk mengelolahnya menjadi desa wisata. Desa Wisata Berkembang, desa wisata embrio yang sudah mulai dikelolah oleh masyarakat dan pemerintah desa, sudah ada swadaya masyarakat/desa untuk mengelolahnya, sudah mulai melaksanakan promosi dan sudah ada wisatawan yang mulai tertarik untuk berkunjung. Desa Wisata Maju, desa wisata yang sudah berkembang dengan adanya berbagai macam fasilitas yang disediakan dengan beroperasi 24 jam, biasanya desa wisata ini dikelola oleh beberapa pihak seperti Pemerintah, Swasta dan Masyarakat.

Dapat dipahami bahwa wisata Desa Banraas termasuk ke dalam Desa wisata berkembang dimana desa ini telah mulai dikelola masyarakat dengan adanya kuliner, penginapan rumah masyarakat dan pemerintah desa telah ikut serta dengan menyediakan beberapa fasilitas wisata seperti transportasi laut, kendaraan untuk keliling desa dan fasilitas lainnya selain itu untuk promosi telah dilakukan lewat instagram dan facebook sehingga wisata Desa Banraas dapat dikenal oleh wisatawan yang datang. Akan tetapi untuk memastikan agar wisata ini terus eksis maka diperlukan berbagai upaya yang dilakukan oleh Pemerintah untuk mendukung pengembangan wisata salah satunya yang dapat dilakukan yaitu dengan memberikan pemahaman konsep kepariwisataan terhadap Pokdarwis dengan melalu pelatihan.

Pemahaman konsep sadar wisata harus mampu menjadi dasar pembentukan sistem pendidikan sadar wisata. Sistem pendidikan sadar wisata merupakan salah satu pendidikan yang dilakukan oleh kelompok sadar wisata (Pokdarwis) dan tergolong dalam pendidikan non-formal. Pendidikan non formal dalam bentuk pelatihan, penyuluhan dan pembinaan masyarakat sekitar area wisata. Pendidikan sadar wisata dimaksudkan mendorong berperan aktif dalam mengembangkan obyek wisata dan melaksanakan kegiatan dalam rangka peningkatan pengetahuan dan wawasan para masyarakat sekitar area wisata dalam bidang kepariwisataan ( Ristyanto, 2016).

Pemerintah Daerah Sumenep telah melakukan pelatihan terhadap pokdarwis di wilayah yang akan dikembangkan objek wisatanya, yaitu wisata segitiga emas, pulau gili labak. Gili genting dan Gili iyang. Pelatihan yang dilakukan dalam rangka mempersiapkan masyarakat yang mampu untuk mengelola wisata. Pelatihan yang dilakukan ini merupakan mitra kerja antara Pemerintah dan Pokdarwis sehingga semua kegiatan yang dilakukan oleh Pokdarwis dibawah Pemerintah Daerah.

Lingkup kegiatan Pokdarwis menurut buku panduan Kelompok Sadar Wisata (2012: 27) adalah berbagai kegiatan yang dapat 
diprogramkan dan dilaksanakan untuk mewujudkan fungsi dan tujuan pembentukan organisasi Pokdarwis. Lingkup kegiatan tersebut meliputi, antara lain: Peningkatan pengetahuan dan wawasan para anggota Pokdarwis dalam bidang kepariwisataan. Hal ini dilakukan dengan dilakukannya pelatihan terhadap pokdarwis lalu pokdarwis dapat melakukan pemberdayaan kepada masyarakat dengan bekal kepariwisataan yang dimilikinya. Seperti halnya yang dilakukan oleh Pemda Sumenep dengan melakukan pemberdayaan kepada Pokdarwis.

Mendorong dan memotivasi masyarakat untuk meningkatkan kualitas lingkungan dan daya tarik pariwisata setempat melalui upayaupaya perwujudan Sapta Pesona. Pokdarwis Andang Taruna melakukan hal ini dengan mewujudkannya dalam bentuk peduli lingkungan wisata dengan bersih-bersih, penyediaan kuliner dan penginapan tanpa merusak lingkungan wisata dengan menggunakan kendaraan yang ramah lingkungan seperti sepeda onthel. Mengumpulkan, mengolah dan memberikan pelayanan informasi kepariwisataan kepada wisatawan dan masyarakat setempat. Dalam hal ini pokdarwis masih belum mampu menyediakan website yang berkaitan dengan kegiatan yang dilakukan di Desa Banraas, informasi yang disediakan dalam bentuk mdia sosial seperti instagram dan facebook tidak ada website resmi yang dibuat untuk Desa Banraas.

Memberikan masukan kepada pemerintah dalam mengembangkan kepariwisataan di daerah setempat. Pokdarwis dalam hal ini menjadi penyambung dari keluhan masyarakat dimana masyarakat desa banraas mengeluhkan bahwa perawatan terhadap berbagai wisata yang ada disana masih belum maksimal dimana anggaran yang didapat dari karcis masuk masih belum memadai sehingga dibutuhkan anggaran yang lain yang berasal dari pemerintah. Terkait rencana pembangunan yang akan dilakukan oleh Pemerintah yaitu akan dibangunnya taman kesehatan didesa tersebut masyarakat memilki antusias yang positif akan tetapi solusi agar pembangunan tersebut tidak merusak lingkungan masyarakat juga menjadi harapan bagi masyarakat desa.

\section{KESIMPULAN}

Pembangunan wisata dalam Pengembangan desa wisata banraas dengan melalui Pokdarwis Andang Taruna telah mampu berperan sebagai penggerak dan mitra Pemerintah dimana masyarakat telah memberikan dukungan serta peran sebagai tuan rumah dalam upaya untuk menciptakan lingkungan dan suasana kondusif yang mampu mendorong tumbuh dan berkembangnya industri pariwisata, sedangkan sebagai mitra telah mampu bekerjasama antara masyarakat dan Pemerintah yang diwujudkan dalam bentuk kegiatan dan program yang dilakukan oleh Pemerintah terkait dengan pengembangan dan pembangunan fasilitas wisata seperti penginapan, transportasi, kuliner dan sebagainya meskipun belum terjalin kerja sama yang maksimal antara Pokdarwis dan Pemerintah sehingga terdapat kendala dalam mewujudkan karakter peduli wisata.

Tterdapat beberapa hal yang perlu diperhatikan yaitu pokdarwis lebih aktif lagi dalam memperkenalkan wisata yang ada dengan dibuatnya profil desa yang berisikan kegiatankegiatan yang dilakuka oleh masyarakat sehingga pengunjung dapat melihat. Serta dalam bekerja sama dengan Pemerintah, Pokdarwis dapat memberikan masukan terhadap pembangunan yang dilakukan sebab dapat merusak lingkungan asri desa Banraas. Untuk biaya pemeliharaan juga diharapkan mampu untuk bekerja sama dengan pihak Pemerintah karena terkait dengan minimnya pendapatan wisata.

\section{REFERENSI}

\section{Literatur}

Moleong, Lexy J., Metodologi Penelitian Kualitatif, Bandung : PT Remaja Rosdakarya, 2007.

Rahim Firmansyah. (2012) Pedoman Kelompok Sadar Wisata. Jakarta: Direktur Jenderal Pengembangan Destinasi Pariwisata Kementerian Pariwisata dan Ekonomi Kreatif.

\section{Jurnal}

Farida, A., Arifien, M., \& Putro, S. (2017). Kontribusi Pendidikan Pokdarwis (Kelompok Sadar Wisata) Terhadap Upaya Pengembangan Desa Wisata Kandri Kota Semarang. Edu Geography, 5(2), 52-59. 
Sentano, I. G. E. F. S., \& Mahadiansah. (2010). Memperkuat Peran Pemerintah Daerah: Memelihara Pariwisata Lokal Yang Berkelanjutan. Jurnal Administrasi Negara (JUAN), 8 (1), 1-20.

Suta, P. W. P., \& Mahagangga, I. G. K. O., (2018). Pengembangan Pariwisata Berbasis Masyarakat: Jurnal Destinast Masyarakat, 5 (1), 144. https://doi.org/1024843/jdepar.2017.v05.i01.p26

Wisatawan, K. (2017). PERANAN KELOMPOK SADAR WISATA UNTUK MENINGKATKAN KEAMANAN WISATAWAN ( Studi Kasus Jerowaru Nusa Tenggara Barat. 2 (02). 1-15.

\section{Peraturan Pemerintah}

Undang-undang Nomor 10 Tahun 2009 Tentang Kepariwisataan. 